\title{
The Role of the School Principal as an Educator: A Study of a Vocational School in Jambi, Indonesia
}

\author{
Mohamad Muspawi ${ }^{1}$
}

\author{
${ }^{1}$ Universitas Jambi \\ Corresponding author.E-mail: muspawi01@gmail.com
}

\begin{abstract}
The progress of a school really depends on the ability of the principal to lead the school. The purpose of this study was to describe the role of the principal as an educator in an effort to advance the school at the Surya Ibu Thehok Vocational High School (VHS) Jambi. Using qualitative methods, data collection used observation, interview, and documentation techniques. Technical analysis of data involved displays, reduction, and conclusions. Checking the validity of the data utilized triangulation. The research subjects consisted of the principal, deputy principal, several teachers, head of administration, and administrative staff. The results showed that the role of the principal as an educator was as follows: 1) Completing teaching preparation. 2) Teaching in class. 3) Providing an example as a good teacher. 4) Maintaining closeness with students. Based on the research results, it can be concluded that the principal has tried to carry out his function as an educator in an effort to advance the school.
\end{abstract}

Keywords: Principal role, Educator, Vocational School.

\section{INTRODUCTION}

A principal has a very important role, the success of a school is largely determined by him in leading. Muspawi [1] likens the existence of a school principal in a school like a captain on a ship, he is the controller and determinant of where the ship will go and dock. Likewise, in a school, the principal is the controller and determinant of what goals will be achieved and where the direction of the school he leads will move. Ismayani, et.al. [2] said that the principal is the driving force, determining the direction of policy towards schools and education at large.

Principals who lead private schools face more challenges than public schools. This is due to several reasons, among others, because public schools have free education programs from the government for students ranging from elementary to secondary levels. This challenge causes private schools to be able to show excellence and increase public interest. Private school principals usually have a lot of problems that must be resolved, such as related to their roles as managers, innovators, entrepreneurs and motivators. As a manager of a private school principal, he must be able to develop programs, move organizations and optimize educational facilities.

The need for skilled workers has led to the emergence of vocational high schools. Soeharto [3] put forward four theoretical arguments about the need for vocational education, namely: 1). Humans demand work because of the need for activity, freedom, power, social recognition and pleasure. 2). Humans are motivated to work because of three aspects, namely, material, cooperation, and self (ego). 3). The urge to work because of psychology, security, sense of belonging and love, interests, respect, self-respect and freedom, wanting information, understanding, love and beauty and personal self-actualization. 4). So urgent is the human need for vocational education to prepare for work.

The urgency of vocational education can be assessed from its function. Sudira [4] argues that vocational education has multi-functions which, if implemented properly, will greatly contribute to the achievement of national development goals. These functions include: 1). Socialization, namely, the transmission and concretization of economic values, solidarity, religion, art and services. 2). Social control, namely, behavior control with the norms of cooperation, order, cleanliness, discipline, honesty, openness. 3). Selection and allocation, namely, preparing, selecting, and placing prospective workers in accordance with labor market demands. 4). Cultural assimilation and conservation, namely, intercultural absorption of the community and maintenance of local culture. 5). Promote change for improvement.

Surya Ibu Vocational High School as one of the private vocational schools in Jambi City offers a major 
or expertise, namely Office Administration. This school, which was founded on April 2, 2002, has received $\mathrm{C}$ accreditation. Based on preliminary observations compiled through the 2019 Basic Education Data [5], Surya Ibu Vocational High School has 5 teachers, 1 educational staff and 75 students from 3 study groups. The facilities and infrastructure include 4 classrooms, 1 laboratory and 1 library. Based on the observations that have been made, it is necessary to research and study in-depth the leadership of the principal at Surya Ibu Vocational High School, the results of which can be useful for the school and also the world of education in general.

\section{METHOD}

The method used in this research was a qualitative method. Qualitative research is a set of carefully planned and meticulous problem-solving methods with a fairly loose design, soft data collection and aimed at constructing a theory concluded through direct induction. Qualitative research emphasizes the collection of data or information in the form of a narrative (interview results and notes on observations and documents). This research was conducted in the city of Jambi, at the Surya Ibu Vocational High School, located in Pakuan Baru Village, South Jambi District. lasts for 6 months from March 2020 to August 2020.

The research subject was the principal of the Surya Vocational High School, the capital city of Jambi, while the object of the study was the principal's role as an educator in managing the school. Information or information providers in this research are called informants, who basically collect responses or opinions from the interviewee regarding a symptom or event. The informants who are the source of the data are the people who can provide the complete information as possible. The informants in this study were the principal and teachers and staff.

Data collection was carried out in two stages. The first stage, literature review by examining various theories regarding leadership, educational organizations and the competence of school principals. In the second stage, the data collection was in accordance with predetermined methods in order to gain a deep understanding of the object of research being observed. Data collection was done by: 1) observation, 2) observation, 3) new interviews and 4) document review. The interviews conducted in this study were structured interviews. Structured interview is options or answers have been provided by the interviewer [6]. The interview can produce the expected information, so the researcher as the interviewer prepares the interview and gives the interview questions to the principal, teacher and staff as the interviewer.

The primary data in this study were the results of interviewing sources in the research object. Interviews with new instructions are information from the principal studied about a specific problem with free- asking techniques but based on the most recent is to obtain specific information and not to get responses or opinions about a problem. Secondary data categorized in this study contained in the document review. This study was conducted to collect data relating to the National Education System Law, Regulation of the Minister of Education and Culture, regional autonomy policy, in this case the Jambi Provincial Education Office and other supporting documents.

Research instruments were also needed by researchers as a way to obtain these data. This research instrument was carried out by researchers to support objective and accurate research data. The instrument used in this study aimed to determine the required data. Analysis is the process of organizing data so that it can be interpreted. Organizing data means categorizing them into patterns, themes or categories. Interpretation or interpretation means giving meaning to analysis, explaining patterns or categories, looking for relationships between various concepts. Interpretation describes the perspective or views of the researcher [7]. In this study, data analysis started from the beginning. The data obtained in the field were immediately written down and analyzed. The steps taken in processing data analysis in this study are as follows: 1) data analysis during data collection, 2) data processing and 3) drawing conclusions and verification.

Data analysis reveals: 1) what data still need to be searched for, 2) what hypotheses to test, 3) what questions to answer, 4) what methods should be used to find new information and 5) what errors should be corrected. Data reduction is used to structure the data findings, which are then grouped into several data categories based on needs so that the result is identification of data in accordance with the type of data required. After the data is reduced, it is continued with the presentation of the data obtained, both primary and secondary, then the level of attainment of the data needs obtained is linked so that it can make it easier for researchers to analyze the data obtained. The data obtained from the start has been tried to draw conclusions which are constantly verified during the study.

\section{RESULT AND DISCUSSION}

\subsection{The Role of the Principal as an Educator in Managing Vocational Schools}

\subsubsection{Creating Excellent Programs that are Characteristic of the School}

Based on the explanation given by the principal, it can be seen that one of the roles of the principal as an educator in managing this school is to create excellent programs that are characteristic of the school. As explained by the principal below:

"I and all the teachers made a superior program that

is the hallmark of the school, which is a sports 
coaching program, in this case volleyball, futsal, football, badminton, we do this because we realize that Our students are weak in academics, so we are trying to be better known in the field of sports, and we are determined to make the field of sport the flagship of our school"

The principal's explanation is also in line with the explanation given by one of the school teachers as follows:

"Our school seeks to maximize the various potentials possessed by students, namely the potential in addition to academics in the form of sports, we do this to address the shortage of our students in the academic field, because as it is understood, the majority of our students in here are transfer students from several schools, and also do not rule out that they are students who have problems in the previous school, on the other hand that our students here can be said to be an abundance of schools in the city of Jambi, so it is understandable that In terms of academic ability, many of them are left behind"

The explanation from the principal and one of the teachers is also in line with the results of the observations that the author has made, which found that there are sports facilities around the school, however, when looking at the feasibility and completeness side, it can be said that the sports facilities in This school is not yet adequate and incomplete to be included in the standard category of athlete development, however, it is commendable the enthusiasm shown by the principal and teachers to strive to make achievements in the field of sports amid the lack of existing facilities.

\subsubsection{Provide Guidance to Teachers to Improve the Teaching and Learning Process}

The role of the two school principals as educators in managing this school is to provide guidance to teachers to improve the teaching and learning process. As explained by the principal as follows:

"In my context as an educator in managing this school, among the roles I do is to provide guidance to teachers to improve the quality of the teaching and learning process, this is a very important thing to do, considering that one of the reflections of the success of a school is how the quality of the process is. teaching and learning displayed. Therefore, I try my best to provide guidance to the teachers in this school so that they are able to carry out their duties properly "

The information conveyed by the principal corresponds to the information conveyed by one of the school teachers as follows:

"The principal always provides guidance to us teachers who teach at this school, namely regarding improving the quality of teaching services, various important information related to learning is conveyed to us, we are also given the opportunity to share ideas and exchange thoughts in that moment, the principal is also give us the task we have to carry out "

The results of observations made by the author found documentary evidence of coaching activities that have been carried out by the principal of the teachers at the school, namely in the form of photos of activities and in the form of documents of assignments that have been done by the teachers.

The leadership of the principal is needed in the existence of a school, Moran [8] knows that the principal has a relationship with teacher professionalism. Botha [9] also said that school leadership is very important to foster and direct teachers and education personnel to work better and more responsibly.

\subsubsection{Conduct Classroom Supervision}

Based on the explanation given by the principal, it is known that another thing done by the principal in his role as an educator in managing this school is to carry out classroom supervision, as the following explanation:

"Yes, apart from the two things that I have done as I have said, the next is that in an effort to realize the progress of this school in my context as an educator, I conduct classroom supervision, namely visiting classes in this school, in in order to see firsthand how the state of the implementation of teaching and learning activities in the class concerned, so when I get something I need to give input on how the teacher teaches or how the process of teaching and learning activities is good, then I supervise the teacher concerned, I give various inputs so that the good things can be maintained and improved and the things that are considered still lacking need to be fixed and and refined in the future ".

What was explained by the principal was also in accordance with what was explained by one of the teachers in this school, which when the writer interviewed him explained the following:

"Occasionally the principal of the school conducts supervision or visits to the class where I teach, she observes the teaching and learning process in my class, then she provides input both to me and to the students in the class, indeed the input was given to me. delivered wisely and wisely and delivered not in front of the class but I was summoned to the principal's office to have a discussion about teaching and learning activities in class "

\subsubsection{Organizing in House Training Activities for Teachers and Education Personnel}

The principal conducts in-house training for teachers and education personnel as an effort to improve professionalism at work, as explained below: 
"I have scheduled an in-house training program for teachers and education personnel, which is a program designed to provide special training on important matters needed by teachers and education personnel. My hope is that through this program teachers and education personnel get additional insight and experience about various matters related to their profession as teachers and as education personnel, so that they can follow the latest information and various developments in the world of education, and they do not miss information about important things that happen in the world of education

The same thing was also conveyed by one of the teachers at this school, as explained below:

"Every now and then the principal holds in-house training aimed at us teachers in this school. In this activity we are given various training we need in carrying out our obligations as teachers. We feel this activity is very useful and very important, because through This activity we get so many valuable experiences and new insights in order to follow the various developments in the world of education

The results of the author's observations also found that there were minutes of in-house training activities carried out by this school and there was also a list of attendees from members or teachers and education staff who participated in these activities. The minutes of meeting notes also inform the agenda for the discussion that was discussed at the in-house training activity

\subsubsection{Provide Direction to Teachers and Education Staff to Always Work Discipline}

The principal tries to provide an explanation to teachers and education personnel so that they are disciplined in their work, this information can be listened to in the following interview results:

"What I can do as an educator in managing this school is to give directions to teachers and education staff so that they really do schedule discipline for disciplinary assignments to enter disciplinary classes to submit reports on activity reports and others, the goal is that teachers and education staff can always show good performance when a job is carried out with full discipline, because many failures that occur are caused by undisciplined "

Explain the collaboration along with the explanation of one of the teachers who teaches at this school as follows:

"On how many occasions the principal has given us directions to teachers and education staff about the importance of working with discipline, the principal tries to set an example, always comes at the beginning and comes home at the end, of course we as teachers and education personnel need to imitate good things indicated by the Principal discipline in work "

Based on the author's research, it was found that there were briefing activities given by the school to the teachers which were carried out several times in the last few months. The material from that direction includes various matters related to the work of the teachers and education personnel at this school, among the material presented is about the importance of discipline in work, and regarding shared responsibility in managing and fostering existing students. This is in line with the research report of Cherian and Daniel [10] that guiding the education of students requires the involvement of all school communities

\subsubsection{Schedule Special Hours for Extracurricular Activities and Student Council}

The principal makes a special schedule for extracurricular activities and Osis activities in this school, it can be listened to in the following interview:

"In my context as a school principal and as a teacher I feel I have a high responsibility for how to deliver students in this school to the gates of success in their lives, among the things that the program for students here is to make special schedules for extra-curricular activities and student council activities, namely in the form of setting a schedule for activities that teachers and students can use to carry out extracurricular activities and student council activities in general do not interfere with the regular schedule of teaching and learning activities "

The information conveyed by the school principal is in line with the explanation given by one of the teachers who is also the student council coach at school as explained below:

"The principal arranges any routine schedule agenda, to be used for the implementation of extracurricular activities and activities, which every day after regular teaching and learning activities have been completed, according to the predetermined schedule various extracurricular activities and student council activities are carried out on In the afternoon, in this case the students are involved all according to the choice of activities they choose based on their talents and interests. "

The activity agenda listed in this school activity book proves that the activity schedule as intended by the principal and one of the teachers was indeed implemented. In the activity book, you can see about the curricular and student council activities that have been implemented and the number of participants who have participated in each. This is in line with the findings of research by Jahiriansyah, et.al. [11] who reported that one of the principal roles as education in managing schools is to develop student potential. 


\subsubsection{Involving Student Council Members in Every School Activity}

The school principal tries to involve OSIS members in every school activity carried out in the school. This information can be considered in the interview results as follows:

"I try to involve student council members in various school activities carried out at this school, the aim is to provide education to student council members so that they know, understand and experience how to be involved in an activity and give experience to them what a commitment and responsibility means. an activity "

The explanation given by the principal is in accordance with the explanation given by one of the teachers as stated in the following interview results:

"The OSIS members in this school are always involved to help the teachers in every activity in this school, they are divided into various parts of the activity in question. Seconds are something that is very important in this school in order to provide education and field experience. directly how to carry out an activity and how to be involved in a committee, our hope is that with the involvement of the OSIS members in every activity it can be used as a capital for their life journey in the future $"$.

Information obtained from the principal and the school teacher with the observational data the author obtained, namely that there are several names of OSIS members listed in various activity decisions in this school.

\subsection{Constraints Faced by the Principal}

\subsubsection{Students' Enthusiasm for Learning is Low}

Among the obstacles experienced by the Principal in his position as an educator is the low enthusiasm for learning of the students. This can be noted in the following interview results:

"The main obstacle for me in this nation as an educator in this school is the lack of enthusiasm for learning from the students. This is understandable due to the fact that most of the students here are transfer students from other schools who are generally problematic. in their original school and they moved here, so it is understandable that from the perspective of enthusiasm for learning is low, so I don't push so much that they study well as expected "

The principal is the same as the explanation given by one of the teachers at this school as follows:

"Yes, among the obstacles that come from this school is the problem of the seriousness and enthusiasm of learning of the students who are not very good, which is an obstacle from year to year that we experience at this school. But with school conditions like this we understand all of it, fully. patience to provide the best service to students "

When the authors made observations in this school, it was found that the majority of students did not concentrate in learning, and it was also seen that some of them were doing things outside the context of ongoing learning.

\subsubsection{Weak School Finances}

The second obstacle faced by school principals as educators in this school is the weakness of school finances. This can be understood from the explanation as follows:

"The obstacles faced in managing this school include weak school finances, so that many good things that are thought of as well as many ideas that teachers have cannot be implemented into reality, this is due to weak school finances. We do not reduce our enthusiasm for work. We already understand and understand the state of school finances. So, there are not so many positive things that we can do in this school when activities need large financial support "

The explanation given by the principal was also in line with the explanation given by one of the teachers in this school as follows:

"Another obstacle faced by this school is the problem of minimal school finances. So that with limited funding, there are not so many programs that can be implemented in this school. However, in the midst of this situation we are still trying to carry out activities that are affordable. by existing funds "

The explanation from the principal and one of the teachers is also consistent with the results of the author's observations where the author found that the state of the cash owned by this school was not able to fund large-scale activities, let alone to build expensive infrastructure and facilities. The minimal financial condition of the school is understandable because the income of this school only relies on monthly money from students and and some assistance from the government or donors, which are also not many.

\section{CONCLUSION}

The conclusioan showed that the role of the principal as an educator was as follows: 1) Completing teaching preparation. 2) Teaching in class. 3) Providing an example as a good teacher. 4) Maintaining closeness with students. Based on the research results, it can be concluded that the principal has tried to carry out his function as an educator in an effort to advance the school.

\section{REFERENCES}

[1] Muspawi, Mohamad. (2020). Strategi Menjadi Kepala Sekolah Profesional. Jurnal Ilmiah 
Universitas Batanghari Jambi, 20 (2), Juli 2020, pp.402-409. DOI 0.33087/jiubj.v20i2.938. ISSN 1411-8939 (Online) | ISSN 2549-4236 (Print).

[2] Ismayani, A I, Niswaty, R, \& Darwis, M (2015). Peranan kepala sekolah sebagai leader di SMA negeri 8 kabupaten Bulukumba. Ad'ministrare, Vol. 2 No. 2, Juli - Desember 2015. eISSN: 2541-1306.p-ISSN 2407-1765 https://ojs.unm.ac.id/administrare/article/view/1 527. https://doi.org/10.26858/ja.v2i2.1527

[3] Soeharto. (1998). Desain Instruksional: Sebuah Pendekatan Praktis untuk Pendidikan Teknologi dan Kejuruan. Jakarta: Departemen Pendidkan dan Kebudayaan, Direktorat Jenderal Pendidkan Tinggi, Proyek Pengembangan Lembaga Pendidikan Tenaga Kependidikan.

[4] Sudira, Putu, MP. (2009). Pendidikan Vokasi Suatu Pilihan. [Online]. Tersedia: http://blog.uny.ac.id/putupanji/2009/03/17/pendi dikan-vokasi-suatupilihan/. Diakses 27 September 2019.

[5] Direktorat Jenderal Pendidikan Dasar dan Menengah. (2019). Data Pokok Pendidikan SMK Swasta Surya Ibu Kota Jambi. Kementerian Pendidikan dan Kebudayaan https://dapo.dikdasmen.kemdikbud.go.id/sekola h/2CCB713999AC20809677. Diakses 2 Januari 2020.

[6] Wirawan. (2012). Evaluasi: Teori, Model, Standar, Aplikasi dan Profesi. Cetakan kedua. Jakarta: Rajawali Pers.
[7] Nasution, S. (1999). Metode Penelitian Naturalistik Kualitatif. Bandung: Tarsito.

[8] Mora, Megan Tschannen. (2009). Fostering Teacher Professionalism in Schools The Role of Leadership Orientation and Trust. Educational Administration Quarterly Volume 45 Number 2 April 2009 217-247: journals.sagepub.com/doi/pdf/10.1177/001316 1 X08330501.

[9] Botha, R.J. (2004). Excellence in leadership: demands on the professional school principal. South African Journal of Education. Vol 24(3) 239-243.

[10] Cherian, F. \& Daniel, Y. (2008). Principal leadership in new teacher induction: Becoming agents of change. International Journal of Education Policy and Leadership 3(2). Retrieved [DATE] from http://www.ijepl.org.

[11] Jahiriansyah, Wahyudi, dan M. Syukri. (2013). Peran Kepala Sekolah Sebagai Pendidik Dalam Meningkatkan Kompetensi Pedagogik Guru. Jurnal Pendidikan dan Pembelajaran Khatulistiwa. Vol 2, No 10 (2013). e-ISSN : 2715-2723.

https://jurnal.untan.ac.id/index.php/jpdpb/articl e/view/3591 